Revista de la red interuniversitaria de estudios sobre las literaturas rioplatenses contemporáneas en Francia

19 | 2018

La rebelión de los hijos: el judaísmo en la literatura latinoamericana contemporánea entre tradición y asimilación

\title{
Disipar el vacío, renovar la transmisión: la memoria del detalle en Carta a un padre de Edgardo Cozarinsky
}

\author{
Maya González Roux
}

\section{OpenEdition}

\section{Journals}

Edición electrónica

URL: http://journals.openedition.org/lirico/6426

DOI: $10.4000 /$ lirico.6426

ISSN: 2262-8339

Editor

Réseau interuniversitaire d'étude des littératures contemporaines du Río de la Plata

Referencia electrónica

Maya González Roux, « Disipar el vacío, renovar la transmisión: la memoria del detalle en Carta a un padre de Edgardo Cozarinsky », Cuadernos LIRICO [En línea], 19 | 2018, Puesto en línea el 20 enero 2019, consultado el 30 abril 2019. URL : http://journals.openedition.org/lirico/6426 ; DOI : 10.4000/ lirico.6426

Este documento fue generado automáticamente el 30 abril 2019.

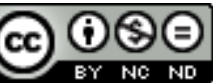

Cuadernos LIRICO está distribuido bajo una Licencia Creative Commons Atribución-NoComercialSinDerivar 4.0 Internacional. 


\title{
Disipar el vacío, renovar la transmisión: la memoria del detalle en Carta a un padre de Edgardo Cozarinsky
}

\author{
Maya González Roux
}

"Los cuentos no se inventan, se heredan"

E. Cozarinsky, El rufián moldavo

El regreso -principio generador, impulso de Carta a un padre (2013)- revela una pérdida, la del padre, y también la interrupción de una historia, la del propio cineasta. Porque la pérdida produce un corte en la transmisión de una historia, este film es el testimonio de la necesidad de suplir el silencio que sigue a esa pérdida y que toma una forma singular, la de una pesquisa. Como en gran parte de la obra literaria y cinematográfica de Edgardo Cozarinsky, el film se dispara con una interrogación: "Para mí [el] pasado [de mi padre] es solo una pregunta", desliza la voz en off al comienzo del film. Es decir, ¿qué queda despué $\mathrm{s}$ de la pérdida y cómo hablar de ella?

Ya desde el título con la mención al padre, Cozarinsky subraya los orígenes. La interrupción en la transmisión, cuando se la asocia a los orígenes, es fundamental en la medida que expresa un malestar mayor que se refiere a la incertidumbre sobre el origen. De esto daría cuenta la gran profusión de los "relatos de filiación", que reconoce Dominique Viart en la literatura francesa a partir de los años 1980, una narrativa que es prueba del fracaso en la transmisión de una historia. En términos de literatura, este fracaso demoledor es el vacío de la palabra, "el silencio de los padres" (Viart 2009: 95-98). A esta incertidumbre, consecuencia del desencantamiento propio de nuestra época, le sigue una desvalorización general de todos los relatos que permiten instaurar un vínculo al situarse uno mismo en una Historia, singular y colectiva, saber de dónde uno viene y conocer aquello que hereda. Es decir, ya no estaríamos en un mundo que asegura la transmisión de una historia y tampoco estaríamos ante una herencia sólida, conformada por una memoria capaz de vincular el pasado con el presente. La continuidad entre las 
generaciones ya no puede establecerse a través del legado de una memoria y el sujeto debe crear una suerte de relato identitario que le permita inscribirse en una línea, en una historia, en su propia genealogía. Entonces, podría decirse que, si existe una herencia, esta es más bien porosa, intermitente, imprecisa. Se trata de una época desheredada en la que los relatos de filiación vienen a instalarse como una respuesta literaria que nuestro tiempo propone a nuestra desorientación. La respuesta literaria -o mejor, cinematográfica, en el caso de Carta a un padre- es la posibilidad para abrir un interrogante aún mayor: ¿qué puede decir la literatura hoy sobre ese capítulo vacío de la memoria que conforma el pasado relativo a los padres? Si el "relato de filiación" es el síntoma de una situación histórica marcada por las lagunas, que deriva en una creciente inquietud por la memoria, ¿qué formas estéticas promueve este silencio? Esta pregunta es todavía más pertinente en la medida que esta forma estética es acorde al interés por una memoria concentrada en pequeños objetos -como la madeleine de Proust- que permiten conocer el pasado a una escala más humana. Porque ese acontecimiento pasado no debe ser, entonces, necesariamente histórico, sino que también puede provenir del ámbito más íntimo, la pérdida existencial que Carta a un padre intenta delinear se hace expresiva a través de pequeños objetos cotidianos, de fotografías, de citas, del testimonio y de recuerdos ajenos. De este modo, aquel objeto que a simple vista puede parecer insignificante es con frecuencia más expresivo del pasado o tiene más capacidad para traducir cualquier acontecimiento: por sobre la descripción objetiva, Cozarinsky elige restituir lo perdido, y colmar el silencio, a partir del detalle de un objeto o evento singular.

Es imposible no pensar en la "Carta al padre" de Kafka; sin embargo, mientras que esta se presenta como una ruptura con el pasado, Cozarinsky busca allí una respuesta a la carencia, al silencio justamente, del presente. Ruptura en uno, enlace en el otro. Además, si la carta de Kafka contiene muy pocas anécdotas y escasos recuerdos, el film de Cozarinsky abunda en relatos menores, referidos por otros, y en evocaciones y citas ajenas. Pero hay un punto de encuentro, pues tanto el texto como el film surgen de una necesidad por encontrar una respuesta: mientras que Kafka intenta responder por qué afirma tenerle miedo, Cozarinsky busca saber quién fue su padre. Lo que cada uno ensaya no es más que un simulacro de respuesta, como lo deja entrever en varias oportunidades Cozarinsky, pues en la realidad, como escribe Kafka, "las cosas no encajan tan limpiamente como los razonamientos de [la] carta; la vida es algo más que un simple rompecabezas" (trad. Andrés Sánchez Pascual y Joan Parra Contreras 2000: 855). ${ }^{1}$ Tal vez por eso mismo el film no se propone indagar y encontrar una certeza, sino ofrecer una conjetura como respuesta a la pérdida y al silencio. Es así que Cozarinsky decide viajar a la tierra natal de su padre -el pueblo de Villa Clara en la provincia de Entre Ríos- con el objetivo de conocer más acerca de la infancia y juventud del padre, muerto cuando el cineasta tenía solo 20 años. Para encontrar alguna respuesta, Cozarinsky dará espacio a distintas voces - una prima de la familia que aún vive en Entre Ríos, el guardián de un cementerio, el responsable de un museo, algún vecino anónimo-, que en el film aparecerán alternadas con la voz del cineasta relatando otros acontecimientos que ya no son propios al ámbito familiar o a la vida del pequeño pueblo. Se trata de la historia sobre la inmigración de los judíos en Argentina, hacia fines del siglo XIX, que se instalaron en la provincia de Entre Ríos. Este hecho histórico aparece en el film entrelazado con episodios de la vida cotidiana de los inmigrantes y con la historia familiar del cineasta, y es la voz del cineasta la que cruza y enlaza todas las historias. 


\section{El sabor de la memoria}

Desde las grandes metrópolis hasta el interior solitario de las tierras entrerrianas, ese es el trayecto que dibuja la trilogía que concluye Carta a un padre, y que se inicia con Apuntes para una biografía imaginaria (2010). En este primer film, la voz en off indaga y arma una biografía, la del propio Cozarinsky, a partir de diversos materiales: recortes, imágenes seleccionadas de documentales, o bien imágenes que aparecen en films anteriores siempre de Cozarinsky-, o incluso algún material que desechó durante el montaje de films como La guerra de un solo hombre (1981), Boulevards del crepúsculo (1992) y El violín de Rothschild (1996). Son todos fragmentos, apuntes justamente que no disimulan su naturaleza, la de ser restos de otras películas que, reunidos, sugieren "una vida". Porque se trata de eso: explorar, de manera sesgada, una vida a partir de fragmentos de una obra. No sorprende, en este sentido, percibir nuevamente el trazo borgeano en el trabajo de Cozarinsky ya que Apuntes para una biografía imaginaria evoca una posibilidad de identidad, una versión de sí mismo, "un simulacro, caos de apariencias". ${ }^{2}$ El film resulta ser, gracias al montaje, una biografía imaginaria sobre la propia memoria, literaria y cinematográfica. También Nocturnos (2011), segunda película de la trilogía, se centra en la memoria, pero esta vez de Buenos Aires (una ciudad que Cozarinsky privilegia con frecuencia); en esta ficción, el cineasta cruza dos memorias, una pública y la otra privada, como afirmó. ${ }^{3}$ Más allá de la preeminencia de la noche, momento predilecto para sugerir un ambiente fantasmal -también presente en otras películas y textos literarios- ${ }^{4}$, me interesa mencionar el recurso a la cita, como en Apuntes. Alfredo Le Pera, Constantino Cavafis, Robert Frost, Gottfried Benn, Brecht, Hölderlin, Baudelaire, Borges y Pizarnik, son algunos de los escritores cuyos poemas Nocturnos cita. Quizás, tal como también sucede en Carta a un padre, las citas y las imágenes de archivo son una manera de hacer intervenir el pasado en el presente, de asegurar una continuidad, de recordar que "el pasado no está muerto, ni siquiera ha pasado", tal la frase de Faulkner citada por Godard hacia el final de Nocturnos.

Esta trilogía -Apuntes para una biografía imaginaria, Nocturnos y Carta a un padre- traza una suerte de espiral que se concentra progresivamente, de film en film, en la figura del propio cineasta: es un movimiento que parte de la amplitud y el bullicio de las grandes urbes y se dirige hacia el silencioso y casi perdido pueblo de Villa Clara en la provincia de Entre Ríos del film Carta a un padre. O bien, desde las voces de la Historia hasta el murmullo de la historia íntima y personal -los documentos históricos son una presencia constante en Apuntes, mientras que en Carta a un padre, si bien la Historia también asoma, lo hace de modo menos contundente y esto a pesar del uso del archivo histórico, como se verá. $Y$ en el centro de este recorrido, la ciudad de Buenos Aires. No sorprende, entonces, que aquello que vincula los tres films sea la memoria: una memoria un poco disgregada que busca subrayar una identidad imaginaria, como ya indica el título Apuntes para una biografía imaginaria, pero sobre todo una identidad provisoria que, por ello mismo, no puede ser más que una versión ${ }^{5}$; o bien, una memoria colectiva como lo es en Nocturnos y, finalmente, la memoria más íntima, la del padre, que evoca en Carta a un padre.

Por otro lado, es posible ver en esta trilogía una densa concentración de toda la obra de Cozarinsky. Y esto es así porque ella regresa a algunos temas e inquietudes estéticas del autor como lo es, sin lugar a duda, el de la identidad: qué conocemos de uno mismo, y qué podemos conocer del otro. Pero, ante todo, los dos primeros films -del mismo modo que 
muchas narraciones de ficción, crónicas y ensayos- están atravesados por la misma curiosidad hacia personajes marcados por la ciudad. En este sentido, la de Cozarinsky es la voz de un testigo del siglo XX que ha vivido y ha sido permeado por el pulso de las grandes metrópolis: de Buenos Aires a París, de Londres a Berlín, pasando por Lisboa, $\mathrm{T}$ ánger, Sevilla y grandes ciudades de Europa del Este como Odessa (Ucrania) o países como Moldavia de donde provienen sus ancestros. Su obra podría definirse como una exploración del tránsito cultural porque nace de la atracción por cierto "vagabundeo sin raíces entre culturas y lugares" (Friera $2011 \mathrm{Web),} \mathrm{resaltando} \mathrm{el} \mathrm{marcado} \mathrm{interés} \mathrm{del} \mathrm{autor}$ por el nomadismo y la diáspora. Precisamente, debido a esta inclinación de Cozarinsky -lo que él mismo definió como un "vagabundeo sin raíces entre culturas y lugares" (Friera $2011 \mathrm{Web}$ )-, podría llamar la atención un film como Carta a un padre en la medida en que supone un regreso a la tierra natal del padre, a sus orígenes. Sin embargo, "el origen" tiene aquí un sentido particular que relativiza el término. Algo de esto ya resonaba en su novela Lejos de dónde (2009) que desde el título buscaba atenuar el sentido de la noción de lugar y de origen y que, por ello mismo, podría resumir la errancia del pueblo judío. Al cruzar varias historias, la novela vacía de sentido las expresiones "lejos de dónde" porque "dónde", el punto de origen, no existe.

\section{El hijo de la diáspora}

Bisnieto de askenazis que llegaron a la Argentina a fines del siglo XIX y que se instalaron en Entre Ríos, Cozarinsky durante mucho tiempo no sintió, sin embargo, gran interés por la identidad judía en cuanto tema. No era una negación sino una falta de preocupación. Sin embargo, fue al escuchar una conversación entre dos mujeres en ladino en la isla de Rodas en el año 1978, y luego de una estadía en Salónica tiempo más tarde -en el año 1992 - en la que rememora ese acento escuchado en aquella conversación, que Cozarinsky comenzó a tener interés por lo judío. Gracias a la lengua, entonces, encuentra su propio vínculo con una tradición hasta entonces desconocida (Cozarinsky 2010: 62). Pero además, este giro respecto a sus orígenes también le permite comprender de otro modo su propia experiencia, la partida de la Argentina en 1974 como una forma renovada de aquella vivida por el pueblo judío cinco siglos antes. El lugar físico, el puerto de Rodas desde el que Cozarinsky se reconoce como judío, también es importante. No está en Argentina, sino en el extranjero, es decir que es desde afuera de su país que descubre sus orígenes judíos y que se reconoce, en consecuencia, como un hijo de la diáspora. Y esta declaración es aún más elocuente cuando se regresa a su obra puesto que es posible percibir, y esto a pesar de las primeras declaraciones desinteresadas de Cozarinsky, una indudable presencia de la diáspora. Recalquemos: de su propia diáspora, esto es del sentido singular que el autor le otorga. En Carta a un padre, como se verá más adelante, Cozarinsky recrea el movimiento de la diáspora familiar; pero puede tratarse también de la "diáspora histó rica" como sucede en El violín de Rothschild (1996), film que desde su propia concepción está atravesado por la idea de dispersión. La construcción en tríptico de esta película es el recurso elegido para dar cuenta de la predilección de Cozarinsky por "la transmisión", la cual sin duda también ritma Carta a un padre así como muchos de sus textos literarios. Se trata de la transmisión de un secreto, de un saber, o de una historia y que implica, a su vez, la pérdida, o bien la transformación de aquello que se relata. Y esto es así por la "condición transitoria" de todo relato, condición que señala la imposibilidad de una repetición idéntica, es decir la transformación constante del relato, no solo al momento 
de transmitirse sino también en su propio proceso de formación. Esto es lo que sostiene Cozarinsky en su estudio sobre el chisme -eslabón de una cadena que representa con su tránsito esa condición transitoria- y que también es extensivo a su concepción de todo relato, ya sea literario o cinematográfico, en el que la transmisión tiene un lugar privilegiado (Cozarinsky 2005: 23-25). De este modo, es la transmisión de la ópera inconclusa El violín de Rothschild el motivo que le permite a Cozarinsky recrear una "diá spora idealizada" en este film. ${ }^{6}$ El tríptico se centra en la historia del compositor Shostakóvich quien incita a su estudiante, Benjamin Fleischmann, a componer la ópera del relato "El violín de Rothschild" de Chejov, una ópera que permanece inconclusa durante muchos años ya que en 1941 el joven estudiante se va a la guerra para defender Leningrado junto con las brigadas populares sin jamás regresar. Años más tarde, Shostak óvich recupera el manuscrito y en 1968 presenta su versión conclusa que será inmediatamente prohibida y atacada como "propaganda sionista". El tríptico contiene entonces el relato de Chejov -su representación-, luego la historia del vínculo entre el maestro Shostakóvich y su estudiante Fleischmann -y cómo este comienza a componer la ópera-, y finalmente el relato sobre el legado que recibe Shostakóvich y la conclusión de la ópera. La transmisión vincula entonces los personajes Bronza y Rothschild de la literatura de Chejov, con los compositores Fleischmann y Shostakóvich y, finalmente, con el mismo Cozarinsky. Si se regresa a lo dicho al comienzo, el trabajo e interés por una memoria a escala humana, en esta película -cuyo trasfondo histórico es la Segunda Guerra Mundial y la emigración de los judíos de Polonia- Cozarinsky elige un instrumento, el violín, para finalmente proponer la música como un monumento a la memoria de los muertos de la Segunda Guerra Mundial. Dicho de otro modo, es en el pasaje de la literatura (el cuento de Chejov) a la música (la ópera de Fleischmann y Shostakóvich) y luego a la imagen (la película de Cozarinsky), y con el violín como objeto privilegiado, que se intenta rescatar y transmitir una memoria que de otro modo se disolvería en el silencio. Es también lo que sucede en Carta a un padre.

\section{Una arqueología de la pérdida}

En el comienzo del film, la voz en off, la de Cozarinsky comenta: "Anoche soñé que estaba en Entre Ríos". A él solo se lo puede ver a través de fragmentos, un recurso ya utilizado en otros films -en particular en Boulevares del crepúsculo- y con el que se sugiere una noción provisoria de la identidad. Por ejemplo, Carta a un padre hace un primer plano sobre una mano que sostiene fotos de época, o bien con una vela que busca dar luz a algunas fotos de su padre; en otro momento Cozarinsky se filma de espaldas, o incluso solo su sombra caminando por un sendero entrerriano. El rostro, fragmentado, es solo un perfil, muchas veces oculto por la noche. No se percibe la totalidad y esto es importante en la medida en que Carta a un padre es, justamente, una indagación acerca del pasado sugerido en las líneas del rostro que, como surcos del tiempo, el film intenta captar. Pero si un rostro puede revelar las respuestas del tiempo aquí, sin embargo, en Carta a un padre, las líneas permanecerán difusas porque no se ofrece una respuesta certera. 
“En cada nuevo film, incluyo imágenes de un film anterior” (9m.-14s.)

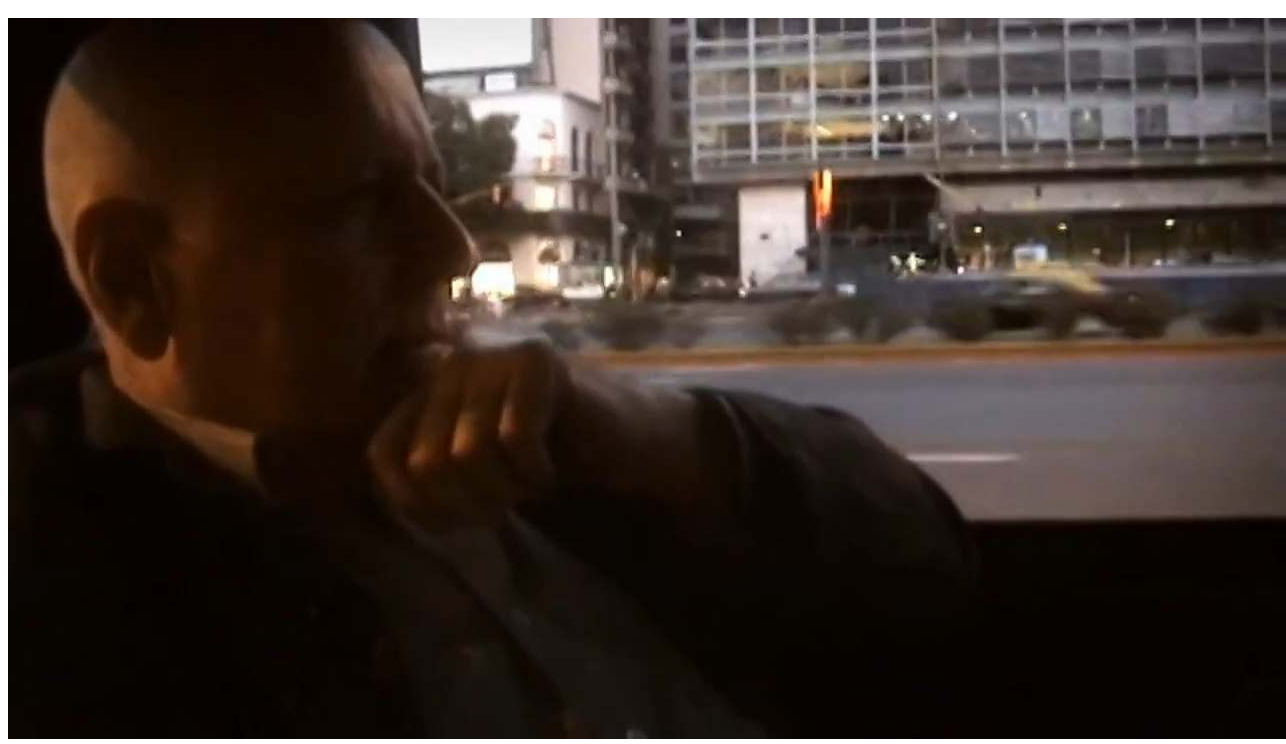

De ahí entonces que pocos minutos después del comienzo, el film arroje una pregunta, un recurso que funciona como disparador en muchos films de Cozarinsky”. "¿Qué hizo que aquel hijo de 'gauchos judíos', según el título creado por Gerchunoff, nacido en Villa Clara, departamento de Villaguay, Entre Ríos, se aventurara a los dieciocho años a ingresar a la armada?", es la pregunta del cineasta al lamentarse no haber abordado este tema con su padre -quien murió cuando él tenía solo veinte años- en las pocas conversaciones que mantuvieron. El montaje le permite evocar el paso del tiempo a través del cruce de imágenes y de geografías disímiles: la naturaleza de Entre Ríos se intercala con París -algunas de estas imágenes pertenecen al film Boulevards du crépuscule -, mientras la voz en off afirma que él nunca estuvo allí, en la tierra del padre; vivió treinta años en aquella capital, conoció muchas ciudades, pero no Entre Ríos. En el centro de este cruce, se sitúa el propio Cozarinsky observando la noche de Buenos Aires desde la ventana de un taxi. El cruce de imágenes es una manera de evocar la prolongación entre las historias, la de su padre y la propia, la continuidad entre el pasado y el presente. Él mismo reconoce que en "cada nuevo film incluyo imágenes de un film anterior. Como los egipcios que en cada templo nuevo incluían en sus cimientos alguna piedra o escombro de un templo anterior. Creían así mantener la continuidad, la del culto, tal vez la de la vida." (Carta a un padre, 9m.-15s.). En distintas ocasiones, a lo largo de Carta a un padre se hará presente este deseo por prolongar aquello destinado a desaparecer, por unir el pasado con el presente, por "impedir que se borre algo que una vez existió". El cuchillo japonés, regalo de su padre de uno de sus viajes, adquiere en este sentido un valor singular. Destinado al ritual del seppuku -el ritual del ceremonial suicidio del soldado para salvar su honor-, y con una inscripción en la vaina que durante mucho tiempo Cozarinsky se negó a traducir por temor a que no fuera más que un mero recuerdo turístico, este objeto aparece en tres oportunidades: primero, como un objeto exótico traído por el padre; luego, como una de las pocas cosas personales que decide llevarse a París -y aquí se hace mención a la reticencia a traducir la inscripción-; y finalmente, en los últimos minutos del film al conocer el sentido de la inscripción. "Para la protección, para no ser herido", son las palabras grabadas en la vaina. 
La pregunta inicial acerca del alejamiento del padre de su tierra natal, es ahora más acuciante, ¿dónde encontrar respuestas?, se pregunta la voz off, ¿en los lugares de la infancia? Cozarinsky decide priorizar la voz del testimonio, en este caso el de una prima porque tal vez sean ellas, las pequeñas historias y las anécdotas, las que ofrezcan algunas pistas. El relato de la prima está plagado de recuerdos, no todos propios, sino relatos referidos: la llegada de sus abuelos a Entre Ríos, las costumbres de los inmigrantes, los primeros encuentros con el "gaucho Piris" quien ofreció leche para los dos pequeños hijos con los que la pareja había llegado desde Odessa en 1894. La prima también desliza alguna que otra anécdota como la del error en el nombre de una de las hijas de los abuelos y tía de Cozarinsky, Rebeca, inscripta como Rifke y de sexo masculino. En realidad, entre el Juez de Paz, cuya borrachera era conocida, y el abuelo de Cozarinsky que hablaba mal el castellano, todos los hijos de la pareja -once en total- fueron mal anotados. En el caso de Rebeca, al cumplir veintiún años el ejército fue a buscarla por desertora... pero se toparon con una joven, muy hermosa, y no con un muchacho.

Estos pequeños relatos, casi como chismes tienen el mismo valor que los objetos que uno conserva, como las fotos descoloridas o las cartas destinadas para otros. "¿Por qué conservamos estas cosas destinadas a desaparecer?", se pregunta la voz en off, “¿será que intentamos hacer durar el tiempo perdido, prolongar los días que nos quedan?" (20m.-30s.) Precisamente, si Cozarinsky también decide ir al museo de Villa Dominguez, que en un comienzo funcionaba como el hotel de inmigrantes, o al museo de las colonias en Villa Clara -hoy un centro de información sobre la inmigración judía promovida por el Barón Hirsch- es para indagar en las pequeñas cosas que esos espacios resguardan. Vale decir, va a buscar las huellas de la inmigración judía en Entre Ríos en los objetos cotidianos que, cargados de pasado, pueden ser más expresivos que la voz de la Historia. Y aquí es necesario detenerse un momento en la presencia de la Historia. Por un lado, hay un trabajo constante en Cozarinsky por insinuar una impotencia y fragilidad del hombre frente a la Historia, una imagen que recuerda la de Ernst Jünger en La guerra de un solo hombre y, más generalmente, la de gran parte de su narrativa: se trata de la ausencia de todo lugar del individuo en la Historia, del vacío en el que están sumergidos sus personajes. Claudio Magris, en su contundente estudio Lontano da dove sobre la obra de Joseph Roth -por cierto, homónima de la novela de Cozarinsky anteriormente citadadefine esta situación, es decir la "exterritorialidad del individuo respecto a la Historia", como la "condición crepuscular" de los personajes del escritor austríaco, condición que expresa la "perfecta tranquilidad" de aquel que "no participa, no espera, no teme; una suerte de situación entre la resignación al vacío y la espera del vacío" (Magris 2009: 113-114). Esto mismo es lo que se distingue en los personajes de Cozarinsky, un estado existencial que, en el marco de la cultura judía, refuerza el sentimiento de jamás estar en un lugar propio y que podría expresarse así: "nosotros los judíos no somos de ningún lugar, no poseemos nada y en ninguna parte del mundo hacemos la Historia." ${ }^{8}$ Es un estado de desarraigo definitivo en el que la noción de origen, tal como enunciado antes, se vuelve relativa y que en Carta a un padre es una pregunta, una más, que permanece sin respuesta: “qué significaba para su padre ser judío?" No era religioso y, aunque no hablara de ellas, para él las únicas raíces estaban en Entre Ríos. Por otro lado, Cozarinsky también introduce la Historia para destronar lo que se conoce como "verdad histórica" y vincular los hechos históricos con los destinos individuales. En Carta a un padre, aunque menos contundente en relación a otros films ${ }^{9}$ pues los eventos históricos están sometidos a la impronta de la voz de los "personajes menores", Cozarinsky no prescinde, nuevamente, del archivo histórico: aquí son las imágenes del ascenso del nazismo en 
Alemania, seguidas de otras que dan cuenta del evento multitudinario que tuvo lugar en el Luna Park de Buenos Aires en 1938, con esvásticas, y que él entrelaza con su propia historia familiar. El vínculo entre ambos -acontecimientos y destinos- queda así sugerido, pero las preguntas persisten. Pareciera ser que la herencia se transmite menos a través de la Historia, o incluso de los genes, que en los objetos como miniaturas de la memoria que concentran el tiempo. En su estudio sobre los objetos de la memoria, On longing. Narratives of the Miniature, the Gigantic, the Souvenir, the Collection, Susan Stewart analiza la diferencia entre el souvenir y la colección principalmente a partir de la relación con el pasado: mientras que el primero pone el acento en el pasado a través de objetos que, aislados, son comprendidos según una lógica y el tiempo del hombre -precisamente, a "escala humana " como antes mencioné-, la colección pone a su disposición el pasado para reemplazar la historia por otro orden, una clasificación. Por ejemplo, las flores secas, que se suelen colocar bajo un vidrio, vendrían a expresar menos la importancia del objeto en sí que la importancia que el dueño le da a ese objeto (Stewart 1993: 151). Aún más, para pasar a integrar una colección, se debe borrar la marca del origen del objeto (Stewart 1993: 152). En Carta a un padre, justamente, pareciera suceder todo lo contrario con los objetos que Cozarinsky elige: qué mejor ejemplo que el cuchillo japonés con una inscripción sobre la vaina en un idioma desconocido, y que solo se traduce muchos años después, conservando y reforzando su origen. Hay un objeto en particular, y que descubre en el museo de Clara, que parece resumir el valor que el cineasta otorga a los objetos con los que se va encontrando: se trata de un cubo macizo, no muy grande y que cabe entre sus manos, hecho de billetes de banco triturados y compactados, billetes que hablan de crisis endémicas, ahorros volatilizados, proyectos frustrados, ilusiones sin futuro. En las vetas de color, la voz de Cozarinsky cree leer, como en las líneas de una mano, muchos destinos aciagos. Sin embargo, con tono resignado reconoce, una vez más, la única certeza: la de la tierra que permanece.

Museo de la inmigración. El cubo que compacta destinos aciagos (36m.).

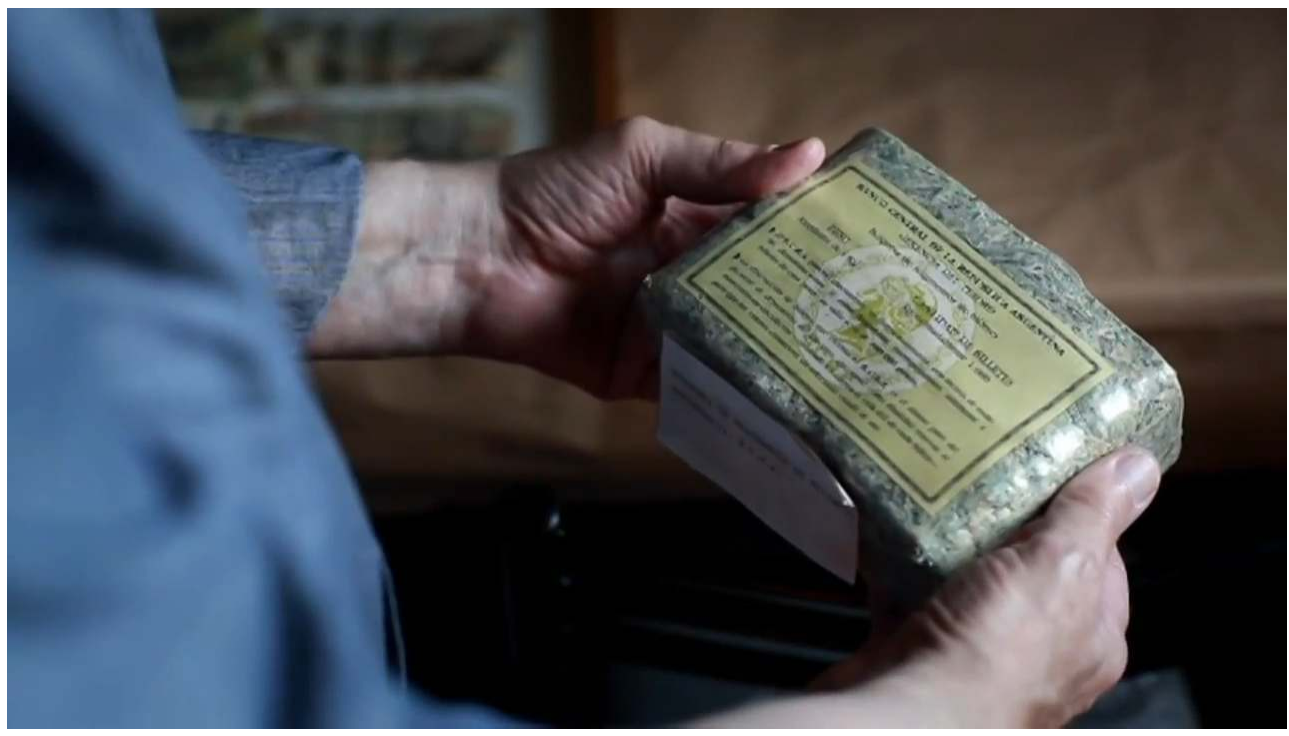

A medida que el film avanza aparecen nuevas preguntas como, por ejemplo, qué encontró su padre durante sus viajes. $Y$ en este punto es posible conjeturar que el film intenta vincular, como si fuera un cruce azaroso más allá del vínculo familiar, la historia del abuelo, con la del padre y la del propio Cozarinsky: el primero, que en 1894 cruzó todo el 
océano en búsqueda de mejores oportunidades; luego el padre, al realizar el camino inverso desde Buenos Aires y visitar muchas ciudades; y finalmente el propio Edgardo Cozarinsky quien decidió vivir entre dos continentes, "entre la palabra escrita y la palabra filmada". Y este cruce, una vez más, se pone deliberadamente en evidencia en otro lugar, en el cementerio, frente a la tumba del abuelo. Es allí que Cozarinsky decide leer una carta del padre al hijo, es decir el abuelo despidiendo a "Mironcito", como llamaban al padre de Edgardo, que en 1919 y desde Buenos Aires se dispuso a partir. La cadena parece continuar cuando el film se detiene en las piedritas que, una al lado de la otra, coloca la mano sobre la tumba. Según la tradición se está "marcando nuestra presencia", como señala el cartel del cementerio Colonia Carmel: "Al dejar una piedrita sobre la tumba de nuestros seres queridos, la marcamos, recordando su memoria. También descargamos parte de nuestro dolor, cumpliendo con el precepto de unir el pasado a nuestro presente" (Carta a un padre, 45m.).

“Marcar nuestra presencia” (45m.)

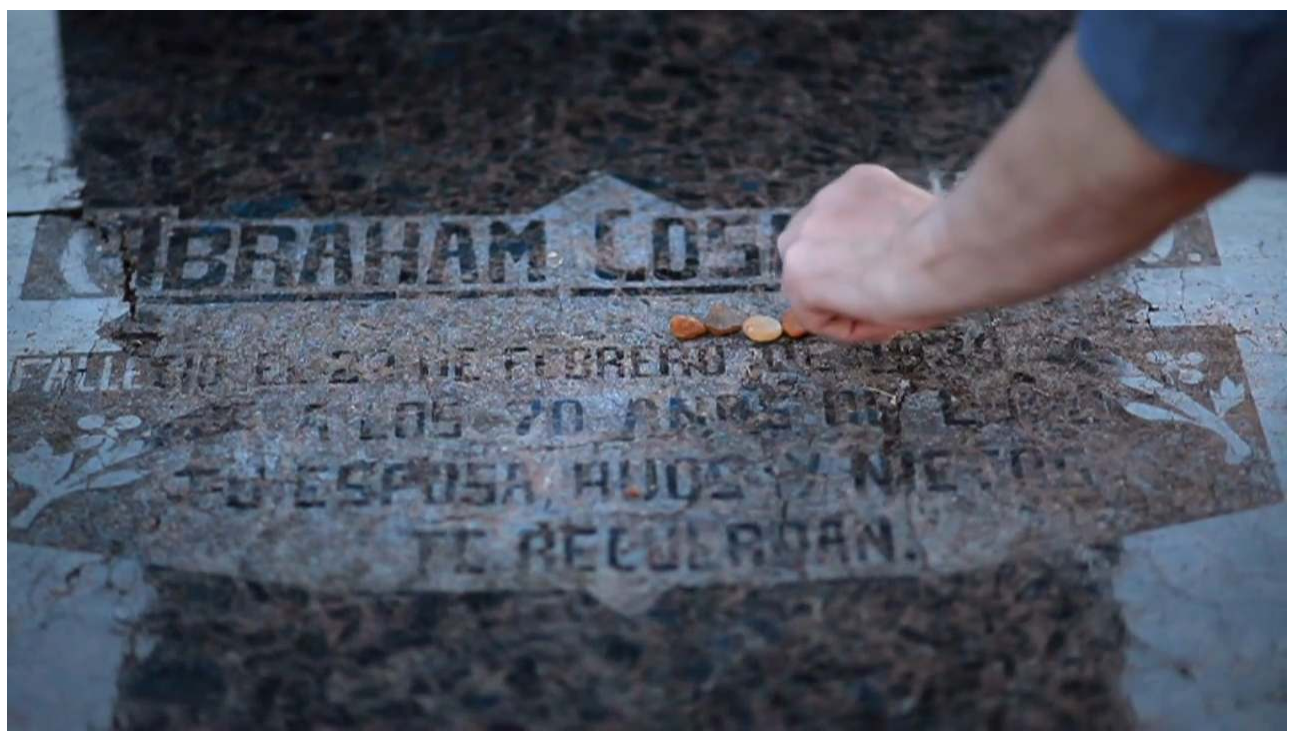

Tal vez el momento más lírico del film, como Cozarinsky ha reconocido, sean sus últimos minutos, cuando el deseo inicial de continuidad se interrumpe y aparece toda una serie de asociaciones libres de su propia búsqueda. La voz reconoce que, una vez en Entre Ríos "duerme sin sueños" y que, al llegar al final del viaje, sus preguntas siguen intactas, sin respuestas. La imagen que acompaña estas palabras es la de una mano hundiéndose en la tierra, la única respuesta o certeza, como antes había mencionado. Y es en esos minutos finales que Cozarinsky se apropia de palabras ajenas, algunas citas dispersas de Tarkovski, Perec, Wilcock, para retener algo, para hacer que "algo sobreviva" y "dejar en alguna parte un surco, una huella, una marca" (Carta a un padre, 49m.). Una última pregunta lo asedia, ¿y si su padre hubiera estado con vida en los años 1970?: ¿qué hubiera sucedido si "su lealtad con la armada, su respeto por el orden, le hubiesen llevado a aceptar lo inaceptable, a ponerse de parte de los verdugos."? Las fotos intactas que recupera del fogón parecen desafiar esta posibilidad y conservar el recuerdo del padre. Estas asociaciones libres de los últimos minutos, asociadas a los grandes planos de los paisajes de Entre Ríos, que acentúan el sentimiento de lejanía del cineasta respecto a esa tierra, son como las digresiones, las conjeturas, los recuerdos propios y ajenos que pautan la búsqueda real e imaginaria de Cozarinsky. Justamente porque esos minutos finales son el 
momento más lírico del film, es ahí que se percibe el pasado, no en tanto objeto de un saber que debe formularse a través de conceptos, sino como el objeto de una experiencia y que, como tal, está sometido a conjeturas o supuestos. Por eso el pasado se convierte en "un conocimiento a escala humana" en el que los objetos, incluso si parecen tenues $u$ oxidados, son embragues de la memoria. $\mathrm{O}$, por el contrario, tal vez habría que decir que, como esos objetos están oxidados, descoloridos y sin brillo son más expresivos del tiempo transcurrido y tienen más capacidad para restituir los hilos perdidos de la historia.

La atención hacia lo ínfimo y los pequeños objetos con los que Carta a un padre se realiza, intenta remediar el "malestar de la transmisión" (Demanze 2008: 36). Reanudar la transmisión significa, de este modo, encontrar una respuesta posible o mejor aún proponer una conjetura. Es decir, al recuperar el recorrido familiar, al imaginar la historia -y sus fisuras- de sus antepasados, el heredero crea un espacio de libertad en el que la herencia ya no es un poderoso determinante que moldea el carácter de su existencia (Demanze 2008: 35-36). Este espacio de libertad -como una respuesta a la pérdida, al silencio- le permite a Cozarinsky recrear su propia diáspora $\mathrm{y}$, con ella, proponer una identidad menos atada a los orígenes y más proclive a las conjeturas, a las versiones, a las citas o palabras ajenas, tal como se escucha hacia el final de Carta a un padre: "Hago mías palabras ajenas. Trato meticulosamente de retener algo, de hacer que algo sobreviva. Quisiera arrebatarle unos pocos fragmentos al vacío que crece. Dejar en alguna parte un surco, una huella, una marca. Aunque solo sean unos pocos signos." (50m.-30s.).

“Mi sombra era la sombra de un joven / y yo también soy la sombra de un joven" (R. Wilcock, "En Velletri": $51 \mathrm{~m} .-30 \mathrm{~s}$.)

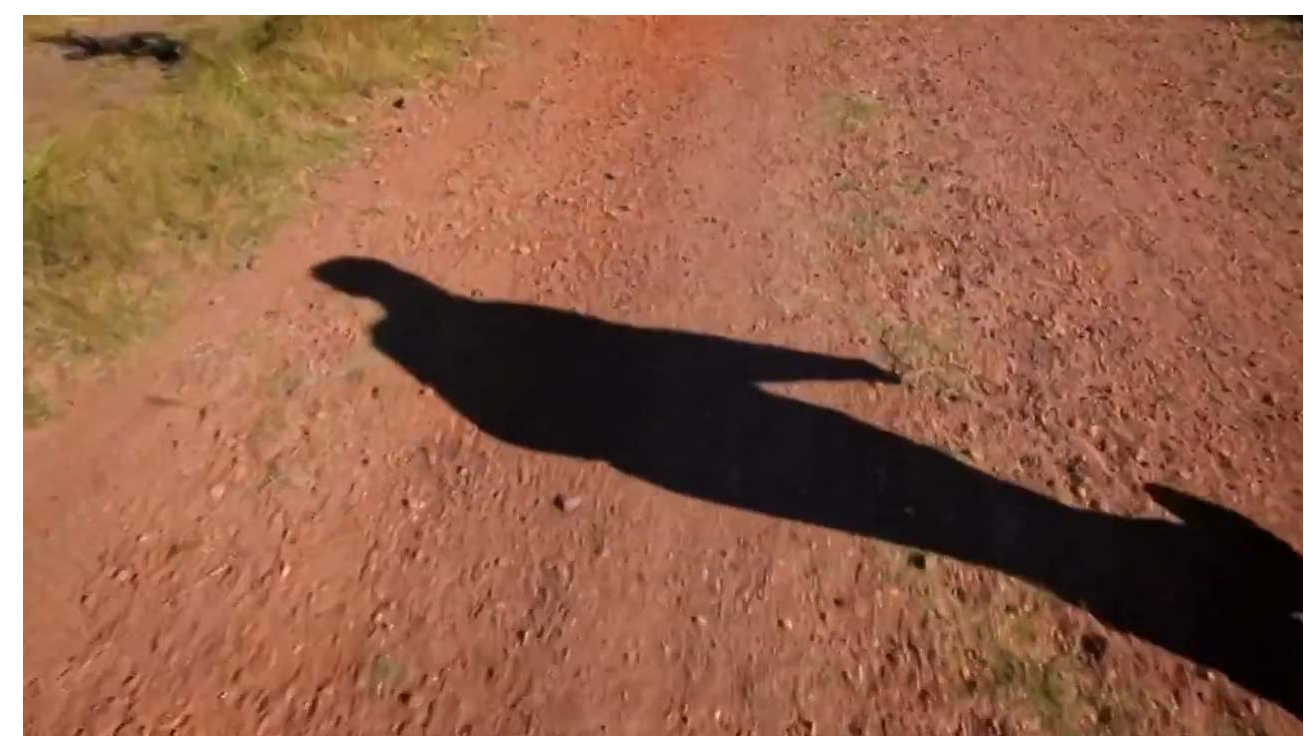




\section{BIBLIOGRAFÍA}

\section{Bibliografía}

Cozarinsky Edgardo, Borges y el cine, Buenos Aires, Editorial Sur, 1974.

---, "Quelques notes autour du film", Le violon de Rothschild, París, Actes Sud, 1996, p. 77-83.

---, Museo del chisme, Buenos Aires, Emecé, 2005.

---, Blues, Buenos Aires, Adriana Hidalgo editora, 2010.

---, "Con la mirada en Buenos Aires”, La Nación, 17 de abril 2012.

Demanze Laurent, Encres orphelines, Librairie José Corti, 2008.

Friera Silvina, "Yo vagabundeo sin raíces entre culturas y lugares”, Página 12, 14 de marzo 2011.

Kafka Franz, "Carta al padre”, Obras Completas II, Barcelona, Galaxia Gutenberg/Círculo de Lectores, 2000. Traducción de Andrés Sánchez Pascual y Joan Parra Contreras.

Magris Claudio, Loin d'où? Joseph Roth et la tradition juive-orientale, París, Éditions du Seuil, 2009. Traducción de Jean Pastureau y Marie-Noëlle Pastureau.

Pic Muriel, W. G. Sebald, L'image papillon. Suivi de W. G. Sebald: L'art de voler, Dijon, Les presses du réel, 2009.

Saraceni Gina, Escribir hacia atrás. Herencia, lengua, memoria, Rosario, Beatriz Viterbo Editora, 2008.

Stewart Susan, On longing. Narratives of the Miniature, the Gigantic, the Souvenir, the Collection, Durham and London, Duke University Press, 1993.

Viart Dominique, “Le silence des pères au principe du 'récit de filiation”, Études françaises n. 45, 2009, Les Presses Universitaires de Montréal, p. 95-112.

\section{Filmografía}

Cozarinsky Edgardo, El violín de Rothschild, 1996.

Cozarinsky Edgardo, Carta a un padre, 2013.

\section{NOTAS}

1. A pesar de las posibles objeciones que se le puedan hacer, Kafka declara haber llegado a "algo tan cercano a la verdad" con su carta, suficiente para tranquilizarlos, al hijo y al padre, y hacer la vida y la muerte más llevaderas. Justamente, estas palabras son elocuentes sobre cómo Cozarinsky tantea también la verdad y cómo se aproxima a ella sabiendo que el resultado será una conjetura.

2. Así se refería Borges al personaje Charles Foster Kane del film Citizen Kane en su reseña "Un film abrumador" para la revista Sur (n. 83, agosto 1941) y que Cozarinsky recoge en su libro Borges y el cine (1974: 64-65).

3. "La memoria pública y privada de la ciudad, creo yo, queda tatuada en sus paredes. Un crimen pasional, una represión policial surgen en blanco y negro, sobreimpresas sobre la imagen en color de los barrios más desastrados." (Cozarinsky 2012 Web). 
4. Un ejemplo de ello son algunos cuentos de La novia de Odessa, las novelas La tercera mañana y Maniobras nocturnas, y las películas Fantômes de Tanger (a pesar de que la nocturnidad queda en segundo plano), En el rojo del atardecer y Ronda nocturna.

5. Un aspecto que por cierto recuerda la noción de narración e Historia que Cozarinsky vincula con el chisme en tanto relato transmitido.

6. "Moi-même j'ai rêvé, bien avant de les réaliser, des images pour le monde disparu du shtetel la première fois où j'ai entendu l'opéra. Cette envie de recréer une diaspora idéalisée, par la musique et le chant, est surgie en même temps que celle de la mettre en conflit avec les 'réalités' grotesques de la période stalinienne." (Cozarinsky 1996: 79).

7. Por ejemplo, en La barraca: Lorca sur les chemins de l'Espagne (1994), Van Gogh et son double (1998), Boulevards (1992), Citizen Langlois (1994). Generalmente, a partir de la formulación de esta pregunta, los films adquieren paulatinamente la forma de una pesquisa y el tono y andar de la voz en off encuentra una semejanza con la de un investigador.

8. "Nous autres Juifs nous ne sommes d'aucun endroit, nous ne possédons rien et nous ne faisons l'Histoire nulle part." (R. Bernstein-Wischnitzer, citado por Magris 2009: 112).

9. Sin duda, La guerra de un solo hombre, íntegramente realizado a partir de archivos históricos (imágenes, documentos, publicidades) y de los diarios del oficial alemán Ernst Jünger, es un claro ejemplo de este trabajo.

\section{RESÚMENES}

El film Carta a un padre (2013) es un viaje hacia el pasado familiar para indagar el silencio en torno al padre. A partir del detalle como lo son los pequeños objetos cotidianos, las fotografías, las citas, el testimonio y los recuerdos ajenos, Cozarinsky realiza una arqueología de la pérdida que intenta reconstruir la memoria silenciada y, con ella, reanudar una transmisión interrumpida: la de su propia historia, hecha de suposiciones y versiones.

Le film Carta a un padre (2013) est un voyage vers le passé familial pour interroger le silence autour du père. C'est à partir du détail -par exemple, les petits objets de la vie quotidienne, les photographies, les citations, le témoignage et les souvenirs d'autrui- que Cozarinsky accomplit une archéologie de la perte pour reconstruire une mémoire passée sous silence et ainsi renouer avec une transmission interrompue : celle de sa propre histoire, faite de suppositions et versions.

The movie "Carta a un padre" (2013) is a journey discovering the family roots which aims at investigating the silence around the character of the father. Based on small details, such as other people's daily-life objects, photographs, quotations, testimony and memories, Cozarinsky looks deeply into the process of loss, in order to reconstruct a silenced collective memory. He aims at resuming an interrupted transmission, that of his own history, made of hypothesis and interpretations. 
ÍNDICE

Keywords: Cozarinsky, memory, transmission, silence, detail

Palabras claves: Cozarinsky, memoria, transmisión, silencio, detalle

Mots-clés: Cozarinsky, mémoire, transmission, silence, détail

\section{AUTOR}

MAYA GONZÁLEZ ROUX

IdIHCS (Universidad Nacional de La Plata) - Conicet

mayagonroux@yahoo.com.ar 